\title{
Digitalization and Ways for the Development of the Electric Energy Industry with the Participation of Consumers: New Challenges for Shaping the Investment Climate
}

\author{
Yegor D. Burda*, Irina O. Volkova, \\ Elizaveta V. Gavrikova and Anna V. Kosygina \\ National Research University Higher School of Economics \\ 20 Myasnitskaya Str., Moscow, 101000, Russia
}

Received 15.03.2019, received in revised form 01.04.2019, accepted 10.04.2019

The electric energy industry plays a crucial role in the technological support of digitalization, and this leads to an increase in the requirements for its development. Leading developed countries are currently under energy transition and are creating innovative, intelligent energy systems (IES) of open type, which include active consumers, distributed generation mechanisms and the introduction of renewable energy sources. One can observe a deep structural transformation, expansion of the range of participants and creation of new value chains. The development of digitalization and IES provides with new opportunities for sustainable development of the economy and society. This stage facilitates the creation of new tasks for the investment climate in the power industry, so the development of an institutional system is justified.

Keywords: electric energy industry, Russian power energy sector, investment climate, smart grid.

This research was supported by the Basic Research Program of the National Research University Higher School of Economics in 2018 under the project no. 5 "Cooperation mechanisms of participants in smart grids. Practicing implementation of the results of fundamental research in the sphere of economy of Russian cities and agglomeration”.

Research area: economics.

Citation: Burda, Ye.D., Volkova, I.O., Gavrikova, E.V., Kosygina, A.V. (2019). Digitalization and ways for the development of the electric energy industry with the participation of consumers: new challenges for shaping the investment climate. J. Sib. Fed. Univ. Humanit. soc. sci., 12(4), 545-564. DOI: 10.17516/1997-1370-0408.

(c) Siberian Federal University. All rights reserved

* Corresponding author E-mail address: yburda@hse.ru

ORCID: 0000-0001-5876-8870 (Burda); 0000-0002-7184-3756 (Volkova); 0000-0002-6210-5022 (Gavrikova);

0000-0003-2342-7122 (Kosygina)

This work is licensed under a Creative Commons Attribution-NonCommercial 4.0 International License (CC BY-NC 4.0). 


\section{Introduction}

The development of digitalization and the appearance of various breakthrough technologies, environmental challenges, as well as the growth of energy consumption, lead to fundamental changes in the further development of both the economy and energy industry, which are interconnected in their change. There can be seen the following mega-trends having a key impact on the development of the energy sector $(\mathrm{PwC}$, 2014): scientific and technological progress (various technological breakthroughs in the energy sector and related fields); climate change and depletion of fossil resources' reserves (increase in average temperature; increase in $\mathrm{CO} 2$ emissions; decrease in proven reserves of fossil fuels); changing requests and preferences of consumers (growing popularity of "product as a service" models, pressing requirements for consumed goods and services); intensified urbanization (rocketing population density in certain cities and the concomitant increase in the burden on their infrastructure).

Due to the influence of mega-trends on the global electric energy industry, multidirectional changes are taking place, with all the diversity of the latter, one can distinguish three basic cases that will have a decisive impact on the industry development, they are often called 3D: Decarbonisation, Decentralization, Digitalization. They have the greatest effect on the development of electric power systems (Fig. 1): decarbonisation is critical in a long-term strategy for reducing $\mathrm{CO} 2$ emissions and expanding the practice of using renewable energy sources; decentralization motivates consumers and requires substantial coordination; Digitalization supports the other two factors and enhances the possibilities of control, automatization and optimization of all elements in the chain of creation and consumption of electrical energy.

Under these conditions, the very approach to the organization of energy systems and markets is changing. Currently, the leading developed countries are creating innovative intellectual energy systems (IES) ${ }^{1}$ that are open in their essence and provide for the integration and active participation of consumers. These systems also adapt to the growing demands of consumers and structural changes in world economy, communities, and the socio-economic systems of various countries. Along with these, an important role is also played by the desire of these countries for energy independence and the energy efficiency; especially it concerns countries importing energy resources with a high share of hydrocarbon fuels.

1 At present, there is a large number of IES definitions (in English the most common term is smart grid), but for this article we chose the most significant definition of the International Energy Agency (EIA), according to which intelligent energy systems (smart grids) are electrical networks that in their work use digital and other modern technologies for monitoring and network management: from electricity sources to end users. 


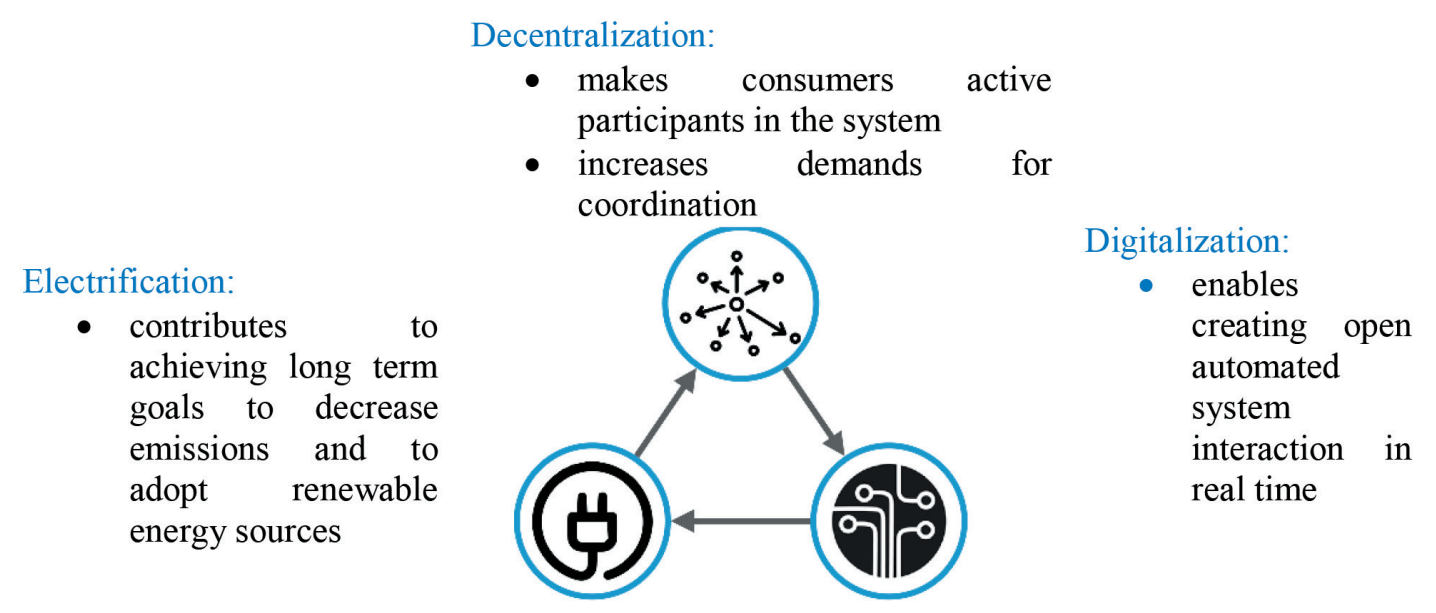

Fig. 1. Three factors determining the further development of the power sector

(World Economic Forum, 2017)

Successful creation of the IES and energy transition based on 3D trends significantly partake in maintaining the competitiveness of economies and the development of digitalization in various industries, and therefore these areas are the main ones for the sustainable development of each country. Creating an IES is innovative in essence, at the same time the range of participants in this sector of production of goods and services starts to expand and include consumers, therefore, it poses serious challenges for attracting investment in the energy sector and creating its investment climate and the investment flow in the economy as a whole, simultaneously changing the conditions for the further development of the country. This article examines the IES development and the emerging new features of the investment climate and the concomitant tasks, moreover, the authors offer suggestions for the development of Russia's intelligent energy system (smart grids, RIES) and the creation of favourable conditions for investment activities in this sphere.

\section{Literature review}

Today, the IES development on the basis of $3 \mathrm{D}$ trends is being actively studied in many areas. The concept of the IES implies not so much the modernization of technologies and equipment, but the revision of the principles of energy system development and the creation of an innovative technological basis for energy sphere. From this point of view, the development of the technological infrastructure is carried out in a breakthrough way, which (unlike the evolutionary one) instead of updating the existing basis ensures the transition to a new level (Kobets, Volkova, 2010), (International Energy Agency, 
2011), (Holkin, Erazvitie, 2014), (Farhangi, 2010), (Gungor et al., 2011), (Fang, Misra \& Yang, 2012). The issues of improving the efficiency of the economy and energy sphere in the transition to the IES are studied both theoretically and on the basis of empirical results (IEA, 2017), (IRENA, 2018), (European Commission, 2018), (World Economic Forum, 2017). In particular, these issues include the detailed study of the IES structure (Wei, 2010), (Kabalci, 2016), (Dong, Zhao \& Xue, 2014), the coordination of the needs and capabilities of all participants (generators, network operators, consumers (Haider, See \& Elmenreich, 2016), (Bahrami, Sheikhi, 2016)), as well as the methods to achieve maximum efficiency of the entire system by minimizing costs and increasing its reliability and stability (International Energy Agency, 2011), (PwC, 2014), (International Energy Agency, 2015), (Khuffash, 2018), (McDaniel, McLaughlin, 2009). The issues of active participation of consumers in the IES and their new opportunities are considered in many works (IBM Institute for Business Value, 2010), (Jansen, Steenbakkers \& Jagers, 2007), (IBM Institute for Business Value, 2007).

The current technological transformation in most countries, as well as in the scientific community, is viewed from the standpoint of an energy transition that changes the energy structure as a whole, not only technical energy systems. Key problems during an energy transition usually arise in areas such as coordination of stakeholders' interests, consumer prices, motivation of participants, sustainability of socio-economic development in general (Geels, 2001), (Geels, Schot, 2007), (Smith, Stirling \& Berkhout, 2005), (Solomon \& Krishna, 2011), (Fouquet, Pearson, 2012), (Steg, Shwom \& Dietz, 2018), (Steg, Perlavic \& van der Werff, 2015), (Andrews-Speed, 2016), (Li, Trutnevyte \& Strachan, 2016). Despite the fact that issues of the investment climate in connection with the IES development are often discussed in the traditional way, the innovative nature of energy sphere development, the integration of consumers into the IES, and the profound transformation of the economy based on 3D trends set new objectives in this area.

\section{Methods}

We rely on the approach taken when examining energy transition tasks, this approach takes into consideration changes in both the technical and social subsystems of the energy sphere, the main technological and structural changes that occur in the energy sphere and economy as a whole in terms of realizing 3D trends and creating an IES. Based on the comprehensive analysis of these factors, we can draw conclusions about the new challenges in the field of the investment climate. 


\section{Creation of IES and digitalization}

\section{Technologies and equipment of IES}

The IES is a new technological basis, supported by a set of progressive technologies that will adapt at different speeds and in different configurations depending on the region's local commercial attractiveness, compatibility with existing technologies, the state of the legal and regulatory framework and investment concepts. In the conditions of digital technology and intellectual energy demands, there arises a new information environment for the production of value based on the interaction of economic agents, where the discrete process logic is replaced by the stream logic, while the load on the energy system becomes smoother, which increases its efficiency, reliability, adaptability, and manageability. We can distinguish such phenomena of technological development as systems and devices for advanced metering, management of energy flows and assets, sensors for monitoring energy systems, virtual power plants, energy management systems, weather forecasting systems, systems of collecting and analyzing big data, smart inverters, etc.

The development of technology creates new conditions for consumers. In general, economic agents are becoming more mobile, and their social and economic ties are becoming global. They have smart energy-receiving devices, control and communications systems, electric transport and corresponding infrastructure, etc. Energy consumers can use technologies of distributed energy (solar panels, wind turbine towers, heat pumps, microinstallations for multi-generation, heat and electricity accumulators, etc.). Digitalization allows consumers to manage their energy supply at a higher level, provides them with more comfortable living conditions and enables to adapt to challenging environmental conditions and to become active participants in power systems.

The novelties include development of bilateral communication channels, involving consumers, the introduction of IoT, IoE, IoS, M2M technologies, artificial intelligence, distributed management systems (DER management system (DERMS)), the formation of big data and information clouds, new broadband formats $(5 \mathrm{G}$, etc.), etc. Integrated energy efficient solutions are used to create virtual power plants, Smart Grid, Smart City, Smart Building systems. In broad terms, there is a dynamic introduction of renewable energy technologies, electric transport, energy efficient solutions for buildings, urban economy, enterprises; integration of local sources of resources. Digitalization brings the management of technology and energy consumption to a new level for end users (households, enterprises, urban economy, etc.), and gives them the opportunity to 
integrate into the power system and unite in order to improve the efficiency of energy and other resources consumption.

The current changes in the energy sphere are characterized by a very fast penetration rate compared to the technologies of the past. Nowadays, the market needs much less time to reach the level of maturity, according to the World Energy Forum's estimates, the ongoing transformation of the energy sector will create more than $\$ 2.4$ billion of added value over the next 10 years (World Economic Forum, 2017).

IES technologies can bring benefit to both developed and developing countries. In energy systems, IES at the stage of their formation can operate in an island mode, and consequently can be incorporated into a regional or national energy system. In developed energy systems, IES technologies can solve the problems of lack of capacity, large fluctuations in demand and aging infrastructure.

\section{Structural changes in the IES markets and new principles of interaction}

\section{between economic agents}

The complex of 3D trends represents the holistic design which assists to the transformation of the power system: electrification (decarbonisation) is the cause, decentralization is the principle of architecture change, digitalization is a key tool for increasing efficiency (Holkin, Chausov, 2018). 3D trends blur traditional boundaries between manufacturers, distributors and consumers, increasing the complexity of the entire system management. The IES development with an open entrance enables consumers to become active participants in the power systems, including the sector of energy production and energy sales, power supply, and system services.

The following changes occur in the emerging IES:

- integration of centralized and distributed energy systems, as well as adjacent energy systems; integration with heat and water supply systems, etc.; integration and intellectualization of house utility systems;

- complication (diversification, multi-level or multi-structure character) of the energy system structure in the following areas: technological structure, property, management system, fuel balance structure, range of goods and services produced, etc.;

- data growth in the information environment, including real time growth, and diversification of conditions for information exchange (continuous bilateral interaction);

- transformation of participants' business models, which is aimed at increasing their adaptability, customer focus, sustainability, and learning ability; 
- complication of development strategies for economic agents and the IES itself;

- formation of new mechanisms for interaction of economic agents, with their possible and diverse participation in the various segments of IES;

- the emergence of new value models, goods and services, created among other ways during the interaction between consumers, manufacturers, and other system participants (IBM Institute for Business Value, 2010), (Jansen, Steenbakkers \& Jagers, 2007);

- increased degree of freedom and greater opportunities for cooperation in the development of the power system both at the local level (smart grid, demand aggregator, virtual station, recycling of secondary energy sources) and at the global level (research, exchange and dissemination of the best experience (including the IES development), training, innovation, consulting, technologies, etc.);

- creation of new value chains and enhanced efficiency along the entire life cycle of production, transformation, use, utilization of energy, including network cooperation method of work;

- creation of new models of retail markets with the active involvement of prosumers and consumers, with the boosted diversity of participants, demand aggregators, storage devices, etc.;

- growth in the number of stakeholders, the complication of their roles in the energy system with a greater variety of utility maximization functions;

- reducing barriers to entry into the IES, the realization of the principle of "Plug and Play".

Under these conditions, there happen changes in the architecture and structure of markets in the IES, the formation of an energy ecosystem, where energy system participants are more interconnected in the context of the new information environment (IBM Institute for Business Value, 2010), (National Technology Initiative (NTI), 2018). The technological basis of intelligent energy sphere involves the transition to multiagent energy system management with the broader participation of consumers, the integration of local energy sources and flexible adaptation to environmental conditions and the efficient use of resources resting on market principles, mechanisms for organizing, managing technological systems and interactions, flexible response to consumer requests in the light of continuous changes in the external environment, and the consolidated assessment of the effects for all process participants (Volkova, 2016). Generally, the IES control system becomes even more decentralized, especially in the generation sector, where the diversification of energy sources is increasing and 


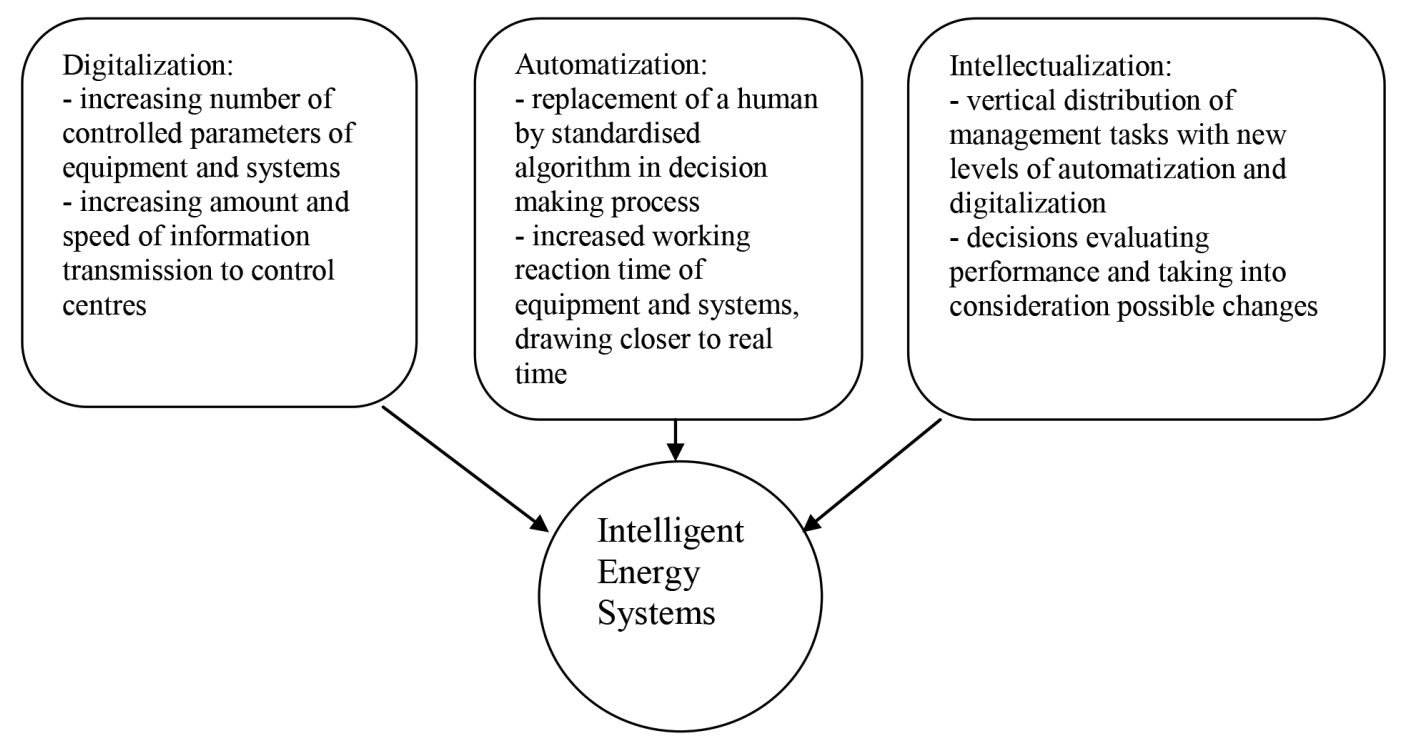

Fig. 2. Modernization of technological process control systems and market operations in IES, adapted from (ERIRAS, 2016)

the diversity of generating technologies, whose power range expands, is also growing. Together with automatization, intelligent measurement tools, artificial intelligence technologies, digital communications, dynamic pricing of energy, power and other goods and services in the energy industry, this process sets new parameters for operational and strategic IES management (Fig. 2), with changes of tasks requiring the participation of economic agents.

On the basis of these changes, the intellectual energy industry acquires new functional qualities, while the economy reaches a higher level of energy supply, with the subsequent increase in the added value in the energy industry and more efficient use of resources.

\section{Investment climate ${ }^{1}$ and IES creation}

New challenges in the development of investment climate

Innovative nature of the IES creates new conditions for investment activity and necessitates new approaches to the creation of the investment climate both in the electric energy industry and in the economy as a whole due to the open nature of the IES and

\footnotetext{
In this article, we use the general definition of the investment climate that the World Bank for Reconstruction and Development proposes. The investment climate is a combination of locally specific factors affecting the capabilities of companies and their incentives to scale up activities and create new jobs based on productive investments. Government policies and actions play a prominent role in the investment climate (The International Bank for Reconstruction..., 2005).
} 
the widespread 3D and mega-trends, the development of breakthrough technologies and structural changes in economies and global world. The following features can be distinguished in the investment process accompanying the IES development:

- the number of participants in the IES and the investment process is expanding, though the mechanisms of coordination between them, especially in the generation sector, are still being created;

- many of the areas (renewable energy sources, technologies for active consumers, digital solutions) are innovative, calling on new financial instruments and other incentives for development, as well as creating favourable conditions for the dissemination of the best practices for business, regulation and consumption;

- competitive and regulatory mechanisms and measures to stimulate the development of network generation contribute to the exacerbation of the reinvestment (underinvestment) problem in the energy system at this stage of development, as well as to the conflict of interests between traditional producers (energy companies), prosumers and active consumers;

- the IES creation is proceeding gradually, through several stages of maturity (Volkova, Kosygina, 2016), which conditions the timely adaptation of the legal framework, regulation and rules of the game as a whole, as well as the investment climate;

- competencies for the IES development and digital technologies are unevenly concentrated in different countries, so there should be intensive international cooperation in many areas, as well as the creation of advantageous conditions for the import of solutions, technologies, equipment, and the conjoined solution of tasks in the field of sustainable development, security and sovereignty;

- transformation of the energy industry and the creation of an IES require new approaches in regulation and new game rules in the energy industry and economy as a whole;

- changes in the global world and climate change cause a changing environment for each country, which imposes higher requirements for the investment climate and complicates the IES development.

Under these conditions, politicians and policymakers need to adapt energy, economic and social policies to ensure the sustainable and effective development of energy industry, the economy and society and also take into account the interdependence of economic agents and the creation of their new business models. Thus, mechanisms of mutual influence of different segments of the economy are formed, which must 


\begin{tabular}{|c|c|}
\hline $\begin{array}{l}\text { Electrical energy industry: } \\
\text { - creation of open market model } \\
\text { of the industry with different } \\
\text { pricing mechanisms; } \\
\text { - integration with other energy } \\
\text { systems; } \\
\text { - diversification of fuel balance } \\
\text { and generation technologies; } \\
\text { - smart management; } \\
\text { - transformation of business } \\
\text { models for participants }\end{array}$ & $\begin{array}{l}\text { Economy: } \\
\text { - transformation of energy } \\
\text { strategies and increased } \\
\text { demands for energy supply to } \\
\text { economic agents; } \\
\text { - efficient management of } \\
\text { demand for energy; } \\
\text { - development of the own } \\
\text { generation; } \\
\text { - individual and comprehensive } \\
\text { solutions to improve energy } \\
\text { efficiency and decrease energy } \\
\text { supply costs; } \\
\text { - decrease of energy supply } \\
\text { risks; } \\
\text { - maintenance of world } \\
\text { competition and sustainable } \\
\text { development }\end{array}$ \\
\hline $\begin{array}{l}\text { External environment: } \\
\text { - transformation of global } \\
\text { economy; } \\
\text { - increasing world demand for } \\
\text { energy; } \\
\text { - environment protection; } \\
\text { - digitalization; } \\
\text { - transformation of world energy } \\
\text { industry; } \\
\text { - transformation of international } \\
\text { relations and treaties }\end{array}$ & $\begin{array}{l}\text { Regulation and energy industry } \\
\text { policy: } \\
\text { - adaptation given changing } \\
\text { conditions in electrical energy } \\
\text { industry and economy; } \\
\text { - balance of stakeholders' } \\
\text { interests }\end{array}$ \\
\hline
\end{tabular}

Fig. 3. Mechanisms and areas of changes in the energy industry transformation, borrowed from Final report under the project No. 5 of Basic Research Program of HSE, 2017

(Volkova et al., 2017)

be addressed during the IES development and in the approaches to the creation of a propitious investment climate (Fig. 3).

In these conditions, a major role is played by the quality of the institutional system, its capability for innovative development, its adaptability, timely solution of emerging problems, enabling to follow the trend of sustainable development factoring in all external and internal challenges. We shall highlight that development in the conditions of such external and internal challenges does not only pose a complex task for the institutional system connected with the IES development, the economical and societal development, but also gives an opportunity to reach a new level of maturity. The principal conditions for achieving this are the following: low barriers to entry into the energy grid; developed and convenient communication standards; a wide range of ways for cooperation and the implementation of various business models; effective protection of property rights; development of the game rules, ensuring coordination of the interests of economic agents simultaneously with the sustainable development of 
the energy industry and economy as a whole. There is a need for coordinated actions of economic agents that in their turn need incentives, resources, knowledge, favourable conditions, mutual trust and willingness to collaborate.

The IES development and the promotion of the introduction of individual technologies are vital for various countries of the world, since this development is one of the ways to realise state policy in terms of ensuring economic growth and the overall development of their economies. Taking into account the scale and speed of development of non-traditional (from the point of view of the classical energy system) products and services, as well as their potential benefits, different states implement various initiatives that create auspicious conditions for the introduction of such elements into energy systems. Among the most common initiatives are the building of roadmaps and strategic plans for the development of the energy sector of economy; project cofinancing; provision of preferential loans; preferential tariffs for new members; changes in regulations and standards (International Energy Agency, 2011).

Hence, the investment climate should provide optimum conditions for the IES creation and the development of digitalization, sustainable development of the economy and society against the backdrop of high uncertainty, when technological situation changes and profound structural alternations occur in the global economy with the new arising environmental challenges. The investment climate should among other factors stimulate the implementation of 3D trends; create favourable opportunities for the creation of active energy strategies for all participants in the economy, not only for the traditional electric energy industry; guarantee flexible adaptation of regulatory, economic and energy policies in the context of high level of uncertainty and variability of environmental conditions; to create facilities and mechanisms for the timely finding of compromise solutions of the numerous problems of the energy system development for the IES stakeholders.

\section{Features of the IES development in Russia}

\section{Opportunities for the IES development in Russia}

The development of intellectual energy industry in Russia began somewhat later than in the leading developed countries. The abundance of primary energy resources, including hydrocarbons, in Russia coupled with the wide distribution of centralized energy supply systems in cities and with the policy of expanding the share of companies in the economy under state control, centralization of the executive branch of power, has withdrawn the attention of regulators and society from many energy efficiency issues. For the time being, the development of intellectual energy sector and 3D trends in 
general is going slowly, but external and internal challenges give it impetus. The need for the IES introduction was stated and acknowledged at the turn of 2010 as a measure to improve the efficiency of the energy industry in the upcoming investment cycle in the electric energy industry (2020-2030) and as a response to growing consumer demands for high quality, low price, greater energy availability and reliability. The industry officials understood that the innovative development of the electric energy, including a profound transformation of technologies, business models of producers and other energy companies, consumer behaviour models, the structure and principles of management and regulation is necessary to solve the internal problems of the Russian economy and energy sphere which are related to risks of losing competitiveness in emerging global markets, rather than just to follow cutting edge foreign trends (Kobets, Volkova, 2010), (Holkin, Erazvitie, 2014), (Centre for strategic research, 2017).

At present, there are the following prerequisites for the development of the intellectual energy system in Russia: "Forecast of the scientific and technological development of the Russian Federation for the period up to 2030" has been compiled; EnergyNET roadmap is being implemented; the State information system of the fuel and energy complex is being developed; the workshops and expert platforms for the development and implementation of EnergyNet and RIES have been created; the pilot projects on intellectual energy have started; the experiments on the creation of intelligent electric grids at the micro level are being conducted, mainly in the network complex; there have been built premises for the production of a number of renewable energy technologies (wind and solar electric plants) and made up incentives for their development in the energy system; pilot generation projects based on secondary energy sources and garbage are being realized. But the strategic vision about the future of intellectual energy sphere in Russia, about the role of consumers, as well as about the mechanisms for its creation has not appeared yet. In this situation the development of IES differs from IES in foreign countries, where the energy transition and intellectual energy systems are developed on the basis of national strategic documents and are determined by the specially created Centre for Socio-Economic Development (Volkova, 2016).

In Russia, the development of intellectual energy systems is viewed within a slightly expanded approach to the traditional industry approach to the development of the electric energy industry, where issues of innovative development are presented to a great extent as tasks for modernizing technologies of the traditional centralized system and production activities of existing energy companies. There is one point to mention: the development of mechanisms for the interaction of economic agents in 
the context of the development of RIES is largely focused on traditional cooperation of large companies which are mostly state-controlled, bearing in mind the opinions of industry experts, government at the federal level. The historic orientation on the scientific research institutes specialised in power sector is also preserved. Although the decision-making system has changed significantly and has become decentralized, the overall approach to addressing energy problems remains largely traditional and outdated. In these conditions the following problems move to the fore:

- the agent-principal problem in relations between the state and the energy companies, the state and the expert community, the energy companies and the expert community;

- concentration of knowledge about energy in a rather narrow expert circle; low level of awareness of energy development trends among specialists from other areas; poor attention to innovation trends, including 3D trends at many levels of strategic planning;

- the dominance of obsolete and routine approaches of specialists to the consideration of problems in the energy sphere, in which systematic optimal solutions are being sought for, but not sufficiently taken into account. These subproblems include:

$\circ$ growth of requirements for electric energy industry in the digitalization development;

o mixed ownership and decentralization of a decision-making system;

o strategies and behaviour of energy sphere and economy stakeholders, especially consumers;

○ impact of a sharp increase in energy prices, a decrease in energy quality and immature customer focused services of energy companies in terms of attracting new clients;

o objective nature of the development of the company's own consumer generation and the importance of this trend for improving energy efficiency and sustainable development of the economy;

$\circ$ the speed and scale of the energy transition in the world and its impact on the development of the global world and the external environment for the Russian economy and energy industry;

o importance of climate change and environmental protection factors and the increasing influence of the international community on the energy policy at the national level;

○ innovative technologies and solutions, including those involving the active participation of consumers, as well as integration with other energy systems; 
O passive role of the state as an energy consumer.

- Slow development and lagging improvement of the electricity market mechanisms, especially at the level of retail markets, when consumers are considered as passive or secondary participants in these processes in the energy system.

\section{RIES and investment climate}

In general, at the state policy level, there is insufficient consideration of the interrelation between the tasks of digitalization of the economy, and the tasks to increase energy efficiency, reduce the anthropogenic load on nature, to ease energy transition, to renew power facilities in the energy sector, to modernize the economy, to improve the quality of life, macroeconomic balance and sustainable development at all levels, as well as investment climate. The tasks are regarded independently. So far, the state energy policy has been biased towards the interests of large energy companies with the insufficient consideration of the possibilities of breakthrough technologies for the country's development. This is also manifested in solving problems associated with the investment climate, which may complicate the development of the Russian economy and reduce its competitiveness. The solution requires, in particular, the development of mechanisms for interaction and coordination of economic agents, for long-term agreements between them, including:

- interaction between the electric energy system, centralized heat and power systems, the household sector, industry as a whole, transport system in cities and settlements, as well as the general economic interaction while realising $3 \mathrm{D}$ trends;

- integration of consumers and prosumers into energy grids;

- transformation of business models of energy companies and other stakeholders of the energy sphere and economy in order to adapt to the conditions of intellectual energy industry and a changing external environment;

- creation of value chains in intellectual energy industry, integrating the capabilities of producers, consumers and other participants of the energy system;

- development of coordination mechanisms between economic agents in the field of production, distribution, consumption and secondary energy use; multi-agent energy system management; perspective and innovative development of intelligent energy systems; methods to increase their reliability and efficiency, etc.;

- development of intellectual energy ecosystems;

- improvement of the pricing mechanism for electricity in order to balance the interests of producers in the centralized and distributed segments of the generation sector; 
- coordination of interests of economic agents for the development of power reserve management mechanisms in the energy system;

- development of self-regulation for the energy system participants;

- development of principles, mechanisms and tools for the regulation of intellectual energy industry;

- harmonization of the development strategy for intellectual energy industry, economy and 3D trends.

At the same time, the development potential of RIES is for the most part related to the measures taken outside the existing energy grid. In this regard, it would be expedient to integrate the entire potential for the development of intellectual energy industry and the Russian economy as a whole, which requires:

- raising the level of the IES development from industrial one to general economic;

- integrating the development of 3D trends in the economy by including the effects of active participation of consumers and prosumers in the RIES development strategy and via creating incentives, tools and conditions for their training, modernization of strategies and integration into the energy system;

- realizing the potential for the development of renewable energy sources, the creation of consumer flow, distributed cogeneration in the heat power industry of small cities, energy saving and smart solutions in cities in general, and taking all these tasks into account when building strategies for the development of electric energy industry;

- methodological study of the IES development under the conditions of a socio-technical regime, taking into account the process of changing the technological infrastructure, the mixed nature of ownership and multi-agent management, as well as the network, industry and territorial interconnections of the energy industry, the economy, and the society;

- determining the range of stakeholders based on the RIES inclusive nature and the openness of the Russian economy, with creating conditions for a breakthrough track in the development of intellectual energy industry;

- formulating programmes for the RIES development, taking into account the interaction of socio-technical, techno-economic and political systems, the challenges and constraints of the external environment, the interests of consumers of different categories and the influence of key stakeholders;

- mapping additional contours on the roadmap of the transition to intellectual energy industry in Russia: financial organizations, suppliers, public groups, outsiders (external stakeholders). It is possible that other contours are also needed, for example, the contours of the owners and the contours of the territories management. 
In order to improve the investment climate and the IES development, it is necessary to lay down the rules of the game for the Russian economy and energy industry, taking into account the development of 3D trends, the inclusive nature of the IES and a long period of its evolution under conditions of uncertainty and structural changes. In particular, it is compulsory to determine the paths to the goals in the IES road maps, which provide all the key participants in the smart energy industry, including different categories of consumers, with permanent positive effects from the IES development. Furthermore, following the example of developed countries, it is advisable to do social and economic research concerning the adaptation of the economy and consumers to the IES development at different levels of the socio-economic system. The possible obstacles may be unwillingness of existing economic agents to unite; lack of competencies; lack of financial resources; barriers to the development of new mechanisms for interaction and coordination, organizational forms; underdeveloped telecommunications systems, lack of tools for risk management; political and macroeconomic instability; technological constraints, etc. (Volkova et al., 2016).

\section{Conclusion}

Digitalization based on the IES creation affects the formation of a new structure of the electric power industry, the transformation of business models of participants, the mechanisms of their interaction, the creation of new value chains, and expands the range of stakeholders. A substantial contribution to the successful creation of an innovative intellectual energy system is made by timely solution of investment climate tasks, taking into account the interests of all stakeholders, high uncertainty, variability of the external environment, and stimulating 3D trends in the economy and society. Russia somehow lags behind in the development of innovative areas in the electric power industry, but at the same time it has considerable potential for successful transformation of the economy and energy industry, which can make it possible to go along the path of sustainable development and successfully transform the electric power system and economy.

\section{References}

Andrews-Speed, P. (2016). Applying institutional theory to the low-carbon energy transition. In Energy Research \& Social Science, 13, 216-225.

Bahrami, S., Sheikhi, A. (2016). From Demand Response in Smart Grid Toward Integrated Demand Response in Smart Energy Hub. In IEEE Transactions on Smart Grid, 7(2), 650-658. 
Dong, Z., Zhao, J., \& Y. Xue (2014). From Smart Grid to Energy Internet: Basic Concept and Research Framework. In Automation of Electric Power Systems, 38(15), $1-11$.

ERIRAS. (2016). SMART GRID. (accessed 21 November 2018). Available at ERIRAS: https://www.eriras.ru/data/788/rus

European Commission. (2018). Study on the quality of electricity market data of transmission system operators, electricity supply disruptions, and their impact on the European electricity markets.

Fang, X., Misra, S., G., X., \& D. Yang (2012). Smart Grid - The New and Improved Power Grid: A Survey. In IEEE Communications Surveys \& Tutorials, 14(4), 944-980.

Farhangi, H. (2010). The path of the smart grid. In IEEE Power and Energy Magazine, 8 (1), 18-28.

Fouquet, R., Pearson, P. (2012). Past and prospective energy transitions: Insights from history 1-7. In Energy Policy, 50, 1-7.

Geels, F. (2001). Technological transitions as evolutionary reconfiguration processes: a multi-level perspective and a case-study. In Research Policy, 31, 1257-1274.

Geels, F., Schot, J. (2007). Typology of sociotechnical transition pathways. In Research Policy, 36, 399-417.

Gungor, V., Sahin, D., Kocak, T., Ergut, S., Buccella, C., Cecati, C., \& Hancke, G.P. (2011). Smart Grid Technologies: Communication Technologies and Standards. In IEEE Transactions on Industrial Informatics, 7(4), 529-539.

Haider, H., See, O., \& Elmenreich, W. (2016). A review of residential demand response of smart grid. In Renewable and Sustainable Energy Reviews, 59, 166-178.

Holkin, D. (2014). Architecture of the Smart Grid. (assessed 5 November 2018). Available at: http://erazvitie.org/article/umnie-seti-nachinalutsja-s-srhitekturi

Holkin, D., Chausov, I. (2018). Digital Transition in Russian Power Engineering: in search of meaning. In Energy Policy, 5, 7-16.

IBM Institute for Business Value (2010). Switching perspectives. Creating new business models for a changing world of energy.

IBM Institute for Business Value (2007). Plugging the consumer: Innovating utility business models of the future.

IEA (2017). Energy Efficiency, Paris.

International Energy Agency (2011). Technology Roadmap. Smart Grids, 52. Paris.

International Energy Agency (2015). Smart Grids in Distribution Networks. Roadmap Development and Implementation. Paris. 
IRENA (2018). Global Energy Transformation. A Roadmap to 2050.AbuDhabi.

Jansen, W., Steenbakkers, W. \& Jagers, H. (2007). New Business Models for the Knowledge Economy. Ashgate.

Kabalci, Y. (2016). A survey on smart metering and smart grid communication. In Renewable and Sustainable Energy Reviews, 57, 302-318.

Khuffash, K. (2018). Smart grids - Overview and background information. In Application of Smart Grid Technologies. Case Studies in Saving Electricity in Different Parts of the World, 1-10. Elsevier.

Kniagin, V., Holkin, D. (eds.). (2017). Digital transition in Russian power industry. The Materials from Centre for strategic research. Moscow.

Kobets, B., Volkova, I. (2010). Innovative Development of the Electric Power Industry Based on the Concept of SMART GRID. Moscow, IATs Energiia Publishing.

Li, F., Trutnevyte, E. \& Strachan, N. (2015). A review of socio-technical energy transition (STET) models. In Technological Forecasting and Social Change, 100, 290-305.

McDaniel, P. \& McLaughlin, S. (2009). Security and Privacy Challenges in the Smart Grid. In IEEE Security \& Privacy, 7(3), 75-77.

National Technology Initiative (NTI) (2018). Ecosystem of National Technology Initiative (NTI). (assessed 18 November 2018). Available at: https://www.rvc.ru/ en/eco/

PwC (2014). The road ahead. Gaining momentum from energy transformation, 32.

Smith, A., Stirling, A. \& Berkhout, F. (2005). The governance of sustainable sociotechnical transitions. In Research Policy, 34, 1491-1510.

Solomon, B. \& Krishna, K. (2011). The coming sustainable energy transition: History, strategies, and outlook. In Energy Policy, 39 (11), 7422-7431.

Steg, L., Perlaviciute, G. \& van der Werff E. (2015). Understanding the human dimensions of a sustainable energy transition. In Frontiers in Psychology, 6.

Steg, L., Shwom, R. \& Dietz, T. (2018). What Drives Energy Consumers? Engaging People in a Sustainable Energy Transition. In EEE Power and Energy Magazine, 16(1), 20-28.

The International Bank for Reconstruction and Development, The World Bank (2005). The report on the world development 2005. A Better Investment Climate for Everyone, 32. Washington.

Volkova, I. (2016). Smart Grid in Russia: Assessment of Existing Development Potential. In ECO (12), 90-100. 
Volkova, I., Kosygina, A. (2016). Trends of electric power sector in the light of achievements of theory of reforms. Proceedings of higher educational establishments. In Energy problems, 19-30.

Volkova, I., Yassin, E., Kosygina, A., Burda, Y., Gavrikova, E. \& Kosareva, N.P. (2016). Transformation of structure in the Russian economy: development of intellectual energy sector and of the urban economy. In Final report under the project No. 9 of Basic Research Program of HSE. HSE. Moscow (unpublished).

Volkova, I., Yassin, E., Kosygina, A., Burda, Y., Gavrikova, E. \& Kosareva, N.P. (2017). Some questions of development of retail power markets, urban economy and agglomeration. In Final report under the project No. 5 of Basic Research Program of HSE, 375. Moscow (unpublished).

Wei, C. (2010). A Conceptual Framework for Smart Grid. In the Materials of AsiaPacific Power and Energy Engineering Conference, 1-4. Chengdu.

World Economic Forum (2017). The Future of Electricity. New Technologies Transforming the Grid Edge, 32. Geneva.

\title{
Цифровизация и пути развития электроэнергетики с участием потребителей: новые задачи для формирования инвестиционного климата
}

\author{
Е.Д. Бурда, И.О. Волкова, \\ Е.В. Гаврикова, А.В. Косыгина \\ Национальный исследовательский университет \\ «Высшая школа экономики» \\ Россия, 101000, Москва, ул. Мясницкая, 20
}

\begin{abstract}
Электроэнергетика играет ключевую роль для технологического обеспечения ицифровизации, и это обуславливает рост требований кее развитию. Ведущчие развитьле страны в настоящее время осуществляют энергопереход и создают инновачионные интеллектуальные энергосистемы (ИЭС) открытого типа, которые включают активных потребителей, механизмы распределенной генерации и внедрением возобновляемой энергетики. Происходит глубокая структурная трансформация, расширяется круг участников и формируются новые цุепочки стоимости. Развитие ичифровизации и ИЭС дает новые возможности для устойчивого развития экономики и обществ. На данном этапе формируются новые задачи для инвестиционного климата в электроэнергетике и требуется развитие институциональной системы.
\end{abstract}

Ключевые слова: электроэнергетика, российский энергетический сектор, инвестиционный климат, интеллектуальная энергетическая система. 
Это исследование было выполнено при поддержке Центра фундаментальных исследований Национального исследовательского университета «Высшая школа экономики» в 2018 г. в рамках проекта № 5 «Механизмы взаимодействия экономических агентов в интеллектуальных энергосистемах. Практическое внедрение результатов фундаментальных исследований в сфере экономики российских городов и агломераций».

Научная спещиальность: 08.00.00 - экономические науки. 